\title{
Temperature Optimization and Inhibition Test of Lactobacillus acidophilus Bacteriocin Against Salmonella typhi Bacteria
}

\author{
Siska Telly Pratiwi*, Muhammad Bagas Aditya \\ Department of Microbiology \\ Universitas Jenderal Achmad Yani \\ Cimahi, Indonesia \\ *shes_ziffa@yahoo.co.id, m.bagas.aditya.1998@gmail.com
}

\author{
Endah Hamidah Abbas \\ Department of Anatomical Pathology \\ Universitas Jenderal Achmad Yani \\ Cimahi, Indonesia \\ endah.hamidah123@yahoo.co.id
}

\begin{abstract}
Typhoid fever is an infection of the digestive tract caused by Salmonella typhi bacteria. One of the Lactic Acid Bacteria (LAB) in the digestive tract is Lactobacillus acidophilus which has bacteriocins to protect the digestive tract. Bacteriocin is an antimicrobial protein compound that is bactericidal or bacteriostatic. Bacteriocin protein have an optimum temperature range to provide antimicrobial effect. The aimed of this study was determine the temperature optimization of L.acidophilus bacteriocins on S.typhi growth by agar diffusion method. In this research, the extraction of L.acidophilus ATCC 4356 bacteriocin were treated with a temperature of $400,600,800,1000$, and $1210 \mathrm{C}$. The results of research observations were carried out by measuring the diameter of the inhibition zone in each treatment. The result temperature optimization test for L.acidophilus bacteriocins did not give positive inhibition zone. This is due to several reasons, namely the storage and McFarland 0.5 standard setting is too small to inhibit S.typhi growth. This is evidenced by the preliminary test without McFarland arrangement which can provide $3 \mathrm{~mm}$ diameter inhibition. Therefore, further research is needed related to the use of the Mcfarland standard and its bacteriocin storage.
\end{abstract}

Keywords-bacteriocin, antibacterial, Lactobacillus acidophilus, Salmonella typhi, inhibition

\section{INTRODUCTION}

Typhoid fever is an acute infection caused by Salmonella typhi (S.typhi) bacteria [1]. The therapy given for typhoid fever cases is antibiotics. However, long-term use of antibiotics can cause resistance. Antibiotic resistance results in inefficient treatment of these drugs so that alternative treatments are needed, namely by finding new components of antibiotic compounds, including bacteriocins. Bacteriocins can be produced by Lactobacillus acidophilus (L. acidophilus) which is a species of Lactic Acid Bacteria (LAB).

Bacteriocin is a bactericidal or bacteriostatic antimicrobial protein compound produced by the LAB species group. Bacteriocin can inhibit the growth of food spoilage or pathogenic bacteria [2]. LAB which is a microbiota in the digestive tract and vagina is $L$. acidophilus $[3,4]$. L. acidophilus can inhibit the growth of pathogenic bacteria and can be used as a safe probiotic because of its non-hemolytic characteristics, resistant to acids and resistant to bile salts so that it has the potential as a safe probiotic in the digestive tract [3-6].

Based on previous research, L.acidophilus ATCC 4356 bacteria can be identified and extracted but the bacteriocin has not given positive results in inhibiting S.typhi growth for several reasons, one of which is that the L.acidophilus used is thought to have no bacteriocin gene so that it does not produce bacteriocin protein. In addition, the bacteriocin extraction method is not optimal or the amount of bacteriocin produced is not optimal so that optimization is needed. Temperature has an influence on bacteriocin production so that protein denaturation does not occur [7]. Based on this, researchers are interested in knowing the optimization of the bacteriocin temperature from L.acidophilus as a potential probiotic or antibiotic candidate in inhibiting pathogenic $S$. typhi bacteria in vitro.

\section{METHODS}

This study used L.acidophilus and S.typhi microorganisms which were obtained from imported ATCC bacteria. The samples of this study were L.acidophilus ATCC 4356 grown on MRS Agar media and S. typhi ATCC 6539 bacteria grown on Tryptone Soya Agar (TSA). The bacteria used were The American Type Culture Collection (ATCC) bacteria which were used for research and certified.

L.acidophilus were cultured on MRSA incubated at $37^{\circ} \mathrm{C}$ for 18-24 hours. L.acidophilus was taken from one colony and put into de Man Rogosa Sharp Broth (MRSB) then incubated at $37^{\circ} \mathrm{C}$ for 24 hours $[8,10]$.

S.typhi were cultured on TSA media and the S.typhi culture was taken as much as 1 ose then diluted with $0.85 \% \mathrm{NaCl}$ solution to have the appropriate turbidity according to the standard solution of $0.5 \mathrm{Mc}$. Farland. The bacterial suspension inoculated on MHA media and incubated at $37^{\circ} \mathrm{C}$ for 24 hours to test for bacteriocin activity [9]. 
The identification of S. typhi and L. acidophilus bacteria in this study is by using Gram staining and biochemical tests. includes sugar fermentation tests, carbohydrate fermentation, catalase, indole, urea, motility and simon citrate.

\section{A. Extraction of Bacteriocins}

L.acidophilus suspension with a McFarland standard of 0.5 equivalent to $1.5 \times 10^{8} \mathrm{CFU} / \mathrm{mL}$ was grown in MRSB $5 \mathrm{~mL}$ incubated at $37^{\circ} \mathrm{C}$ for 24 hours. After the incubation was completed, centrifugation was carried out at a speed of 10,000 $\mathrm{rpm}$ at $4^{\circ} \mathrm{C}$ for 15 minutes to separate the cell mass that did not contain bacteriocins from the supernatant. The $\mathrm{pH}$ was adjusted to 6.8 then the filtrate was sterilized with a $0.45 \mu \mathrm{m}$ diameter bacterial filter into a sterile tube to obtain a sterile cell-free supernatant. The supernatant carrying bacteriocin was then tested for bacteriocin activity $[8,10]$.

\section{B. Bacteriocin Sensitivity Test to Proteolytic Enzymes}

Amount $750 \mu \mathrm{L}$ of trypsin enzyme with a concentration of $1 \mathrm{mg} / \mathrm{mL}$ was dissolved in a phosphate buffer $\mathrm{pH} \mathrm{7,6}$. The prepared enzyme was added with a bacteriocin supernatant as much as $250 \mu \mathrm{L}$ and then incubated for 2 hours at $25 \mathrm{oC}$. The filtrate is sterilized with a Millipore filter with a diameter of $0.22 \mu \mathrm{m}$ into a sterile tube. The sterile supernatant of $20 \mu \mathrm{L}$ was immersed in sterile disc paper with a diameter of $5 \mathrm{~mm}$. MHA media containing S. typhi indicator bacteria will be placed on a disc paper on the surface. The diameter of the inhibition zone formed was measured using a caliper around the disc paper after being incubated for 24 hours at $37^{\circ} \mathrm{C}$ [10].

\section{Temperature Optimization of Bacteriocin Activity}

Amount $5 \mathrm{ml}$ of Bacteriocin supernatant each heated at a temperature of $40,60,80$, and $100^{\circ} \mathrm{C}$ for 1 hour on a hot plate and $121^{\circ} \mathrm{C}$ with a pressure of 1 atm for 15 minutes in autoclave with the optimum $\mathrm{pH}$ at $\mathrm{pH}$ 6.8. The bacteriocin activity was tested by agar diffusion method [10].

\section{Bacteriocin Activity Test}

The method used to test the antibacterial activity is the agar diffusion method, $15 \mathrm{~mL}$ of agar $\left(50^{\circ} \mathrm{C}\right)$ was poured into a petri dish and allowed to solidify, then $5 \mu \mathrm{L}$ of S.typhi indicator bacteria aged 24 hours (total $10^{5}-10^{6} \mathrm{cfu} / \mathrm{ml}$ ) was poured over it and let it at $4^{\circ} \mathrm{C}$ for $1 \mathrm{hr}$ [11]

Disc paper with a diameter of $5 \mathrm{~mm}$ was immersed in a sterile supernatant. Disc paper was placed on MHA media containing S.typhi bacteria then incubated for 24 hours at $37^{\circ}$ $\mathrm{C}$. The diameter of inhibition zone generated around the disc paper is measured using a caliper [12].

The calculation of the diameter of inhibition zone uses the following formula:

Inhibition zone diameter :

$$
\frac{(\mathrm{Vd}-\mathrm{Dd})+(\mathrm{Hd}-\mathrm{Dd})}{2}
$$

Information:

$$
\begin{array}{ll}
\mathrm{Vd} & : \text { Vertical diameter } \\
\mathrm{Hd} & : \text { Horizontal diameter } \\
\mathrm{Dd} & : \text { Disc diameter }
\end{array}
$$

The criteria for the strength of antibacterial power based on David and Stout are categorized into a weak category with an inhibition zone diameter of $5 \mathrm{~mm}$ or less, a moderate category with an inhibition zone of 5-10 mm, a strong category with an inhibition zone of $10-20 \mathrm{~mm}$, and a very strong category with an inhibition zone of $20 \mathrm{~mm}$ or more.

Positive control used chloramphenicol disc at a dose of 30 $\mu \mathrm{g}$. Negative control used sterile disc paper (paper disc) soaked for 5 minutes with sterile distilled water [13].

\section{RESULTS AND DISCUSSION}

The culture results of L.acidophilus in this study can be seen microscopically and macroscopically. Macroscopic examination of L.acidophilus was carried out by looking at the morphology of the bacteria on MRSA media. The results of macroscopic examination showed that the culture was round with pinpoint size, grayish-white in color, and impenetrable to light. Microscopic examination that is performed is an examination using Gram stain. The microscope examination results showed that Gram-positive bacteria.

The macroscopic examination of $S$. typhi was carried out by looking at the morphology of the bacteria on the TSA medium. Macroscopic examination results show a round, grayish-white, and impenetrable image. Microscopic examination is performed using Gram stain. The microscope examination results showed Gram negative bacteria.

The biochemical tests in this study could not be carried out due to the limitations of the test media, but the bacteria used for the research were certified ATCC bacteria.

\section{A. Extraction of L.acidophillus Bacteriocins}

The preliminary test of Lacidophilus bacteriocins against S.typhi was carried out on MHA media using the Kirby-Bauer method. Bacteriocin supernatant was dripped onto disc paper by testing three times against the growth of S.typhi bacteria. The preliminary test was carried out without adjusting the temperature, $\mathrm{pH}$, and number of bacterial colonies.

Inhibition zone can be found in the preliminary test. The area of the inhibition zone is $3 \mathrm{~mm}$, so a bacteriocin sensitivity test to proteolytic enzymes is needed to determine whether the inhibition zone is caused by bacteriocin.

\section{B. Bacteriocin Sensitivity Test to Proteolytic Enzymes}

Bacteriocin sensitivity test to proteolytic enzymes was carried out by preparing $750 \mu \mathrm{L}$ of trypsin enzymes with a concentration of $1 \mathrm{mg} / \mathrm{mL}$ dissolved in a phosphate buffer $\mathrm{pH}$ 7.6. The prepared enzyme was added with a bacteriocin supernatant as much as $250 \mu \mathrm{L}$ and incubated for 2 hours at $25 \mathrm{oC}$. 
The filtrate is sterilized with a Millipore filter with a diameter of $0.22 \mu \mathrm{m}$ into a sterile tube. A total of $20 \mu \mathrm{L}$ of sterile supernatant was immersed in sterile disc paper with a diameter of $5 \mathrm{~mm}$. Disc paper is placed on MHA media which contains S.typhi bacteria.

Bacteriocin sensitivity test to trypsin enzyme gave negative results, so it proved in the preliminary test that the inhibition was caused by Lacidophilus bacteriocins. Bacteriocin is a protein compound while the trypsin enzyme is a proteolytic enzyme that can destroy protein compounds so that the inhibition of bacteriocins will not be formed in the bacteriocin sensitivity test to the trypsin enzyme. This eliminates the inhibition formed by other antimicrobials such as lactic acid, hydrogen peroxide, and diacetyl because these compounds are not protein compounds. If the inhibitory power is formed in the bacteriocin sensitivity test to proteolytic enzymes, the inhibition power is formed not by bacteriocin but by other antimicrobials.

\section{Optimization of L.acidophilus Bacteriocin Temperature}

Testing the inhibition of L.acidophilus bacteriocins against S.typhi was carried out by the Kirbybauer method on MHA media. The bacteriocin temperatures tested were 40,60,80,100, and $121^{\circ} \mathrm{C}$, while the chloramphenicol disk as a positive control and distilled water as a negative control on MHA media.

The diameter of inhibition zone can be calculated by measuring the diameter of the clear zone formed minus the diameter of the disc paper. The inhibition zone of each treatment was compared with the control inhibition zone. The results of L.acidophilus bacteriocin inhibition against S.typhi can be seen in table 1 .

TABLE I. TESTING THE INHIBITION OF L.ACIDOPHILUS BACTERIOCINS ON S.TYPHI GROWTH

\begin{tabular}{|l|l|l|l|}
\hline \multirow{2}{*}{ Group } & \multicolumn{3}{|c|}{ Inhibition Zone Diameter Test } \\
\cline { 2 - 4 } & Test 1 & \multicolumn{1}{c|}{ Test 2 } & Test 3 \\
\hline 1 & 22,74 & 23,02 & 23,18 \\
\hline 2 & 0 & 0 & 0 \\
\hline 3 & 0 & 0 & 0 \\
\hline 4 & 0 & 0 & 0 \\
\hline 5 & 0 & 0 & 0 \\
\hline 6 & 0 & 0 & 0 \\
\hline 7 & 0 & 0 & 0 \\
\hline
\end{tabular}

Information:

Group 1: Positive control with chloramphenicol Group 2: Negative control with distilled water Group 3: Test the bacteriocin temperature at $40^{\circ} \mathrm{C}$ Group 4: Test the bacteriocin temperature at $60^{\circ} \mathrm{C}$ Group 5: Test the bacteriocin temperature at $80^{\circ} \mathrm{C}$ Group 6: Test the bacteriocin temperature at $100^{\circ} \mathrm{C}$ Group 7: Test the bacteriocin temperature at $121^{\circ} \mathrm{C}$
Optimization of L.acidophilus bacteriocin temperature did not give positive results on S.typhi growth in this research test but gave positive results in the preliminary test. This shows that L.acidophilus bacteriocin can inhibit the growth of S.typhi but it needs further investigation because the temperature optimization test did not give a positive result. Temperature optimization is carried out to determine the optimum temperature of bacteriocin inhibitory activity. Oh, Kim, and Worobo's research showed that the temperature optimization of L.acidophilus bacteriocins with a temperature of $65^{\circ}$ and $95^{\circ} \mathrm{C}$ still gave $100 \%$ inhibition but at $121^{\circ} \mathrm{C}$ the inhibition power was reduced to $50 \%$ [14]. Hoda Mahrous research showed the results of temperature optimization of L.acidophilus bacteriocins by providing inhibition of $30.15 \%$ at $30^{\circ} \mathrm{C}$, $87.34 \%$ at $60^{\circ} \mathrm{C}$, and $11.12 \%$ at $90^{\circ} \mathrm{C}$ [15]. Based on these data L.acidophilus bacteriocins with temperature test range 30$121^{\circ} \mathrm{C}$ can still have inhibitory power against indicator bacteria but have different optimum inhibition zones.

This research test did not get the results of bacteriocin temperature optimization because it did not give results in the inhibition power of the temperature test group ranging from $40^{\circ}, 60^{\circ}, 80^{\circ}, 100^{\circ}$ and $121^{\circ} \mathrm{C}$. This is thought to be due to several reasons, namely the presence of storing and controlling the number of bacteria with McFarland is too small so that the level of bacteriocin extraction is too little as a result it cannot provide an inhibitory power on S.typhi bacterial growth.

The McFarland used in the study of the temperature optimization test for bacteriocin inhibition using the McFarland 0.5 standard was equivalent to $1.5 \times 10^{8} \mathrm{CFU} / \mathrm{mL}$. The results of Sawitri Pertami's research, namely the inhibition power of L.acidophilus probiotics against the growth of Candida albicans showed that probiotics containing acidocin, lactacin $\mathrm{B}$, lactacin $\mathrm{F}$ with McFarland 6 standards equivalent to $18 \times 10^{8} \mathrm{CFU} / \mathrm{mL}$ and McFarland 8 equivalent to $21 \times 10^{8}$ $\mathrm{CFU} / \mathrm{mL}$ did not provide inhibition of growth. C.albicans, but the standard McFarland 10 equivalent to $30 \times 10^{8}$ can provide inhibition against the growth of $C$. albicans with an average clear zone diameter of $8.24 \mathrm{~mm}$ [16]. Based on these data it is concluded that this bacteriocin temperature optimization test study did not provide inhibition results due to use The small McFarland standard is $0.5 \mathrm{McF}$ arland which is equivalent to $1.5 \times 10^{8} \mathrm{CFU} / \mathrm{mL}$ so that the amount of bacteriocin produced is small as a result it cannot provide inhibition against S.typhi. Standard McFarland owned by the FK UNJANI microbiology laboratory, only has a standard of 0.5 so it cannot be done to improve the McFarland standard.

Another reason for the temperature optimization test for bacteriocin inhibition does not give positive results is the storage time. The storage time occurs because there is a closed laboratory hour, but the extraction time takes a long time so that after incubation it is continued with storage at $4^{\circ} \mathrm{C}$ for 16 hours to be continued. The preliminary test does not carry out storage after incubation because the preliminary test does not require temperature regulation, $\mathrm{pH}$ and $\mathrm{McFarland}$ standards so that the processing time is faster than the bacteriocin temperature optimization test. 
Storage time has an influence on the bacteriocin inhibition zone. Based on the research of Ohenhen, Lactobacillus plantarum provides bacteriocin inhibition against Staphylococcus aureus bacteria at a temperature of $28 \pm 2^{\circ} \mathrm{C}$ gave $5 \mathrm{~mm}$ of inhibitory zone. Bacteriocin stored at $-4^{\circ} \mathrm{C}$ for 7 days gave inhibition to $3 \mathrm{~mm}$. This shows that storage time can reduce the activity of bacteriocin inhibition [17].

Hassanejad Bibalad's research showed that the inhibitory effect was only $40 \%$ of all Lactobacillus isolates against one or more microorganisms. The study found only $6 \%$ of all Lactobacillus isolates had the bacteriocin gene [18]. The bacteriocin gene is required in transcripts to produce bacteriocins.

The preliminary test of this study provides the inhibitory power with a diameter of the inhibition zone of $3 \mathrm{~mm}$. The inhibition zone formed is an inhibitory effect of Lacidophilus bacteriocins because the sensitivity test to proteolytic enzymes gave negative results.

The bacteriocin gene L.acidophilus ATCC 4356 has not yet been identified for the bacteriocin gene classification. Several L.acidophilus genes have been found for bacteriocin, including Acidocin A which belongs to the subclass IIa classification of L.acidophilus TK9201 found in fermented milk, Acidocin B subclass IIb classification on L.acidophilus M46 found in food, and Lactacin B which has not been identified as a subclass on $L$ .acidophilus N2 is found in food [19]. Further research is needed to determine the classification of the bacteriocin gene of L.acidophilus ATCC 4356. Identification of the bacteriocin gene Lacidophilus ATCC 4356 can provide an overview of the mechanism of its inhibitory power. Class IIa bacteriocins such as Acidocin A are listeria-active peptides which are bacteriocins that are active against the genus Listeria / Listerisid (pediocin-like bacteriocins) having amino acid sequences in the $\mathrm{N}$-terminal region which are similar to YGNGVXC and are heat stable. Class IIb Lacidophilus bacteriocins such as Acidocin B consist of two peptides which differ from each other by equal numbers forming pores on the target cell membrane and disrupting the proton gradient of the target cell [20-22].

\section{CONCLUSION}

Based on the research that has been done, it can be concluded that Lactobacillus acidophilus can be identified and extracted bacteriocins. L.acidophilus bacteriocin can inhibit the growth of $S$. typhi seen in the preliminary test which gave an inhibitory power of $3 \mathrm{~mm}$ and the proteolytic enzyme sensitivity test gave negative results. Optimization of temperature inhibition of L.acidophilus bacteriocins did not provide inhibitory results for several reasons, namely the storage time after incubation due to laboratory closing hours and the use of small McFarland standards, namely the standard of 0.5 McFarland, so that the amount of bacteriocin to be produced was small, consequently cannot form the inhibition zone in the test.

\section{ACKNOWLEDGMENT}

The authors would like to thank all the professionals who have helped research and the staff of the Microbiology Laboratory Faculty of Medicine Universitas Jenderal Achmad Yani.

\section{REFERENCES}

[1] World Health Organization, Weekly Epidemiological Record. WHO 2018, [Online]. Retrieved from http://apps.who.int/iris/bitstream/handle/10665/272296/WER9314.pdf?u $\mathrm{a}=1$, accessed June 11 st 2020

[2] Axelsson, L. Eijsink, D. Diep, L. Harvastein, H. Holo, and I. Nes, "Production of Class II Bacteriocins by Lactic Acid Bacteria," Antonie Van Leeuw, vol. 81, pp. 639-54, 2002

[3] Y. Wang, A. Li, X. Jiang, H. Zhang, and K. Mehmood, "Probiotic Potential of Leuconostoc pseudomesenteroides and Lactobacillus Strains Isolated From Yaks". Frontiers in Microbiology, vol. 9, pp. 1-10, 2018.

[4] A. Kusmarwati and N. Indriarti, "Characterization of Lactic Acid Bacteria from Rusip as Probiotic Agent," JPB Kelautan dan Perikanan, vol. 7, no. 2, pp. 159-170, 2012

[5] D.E. O'Hanlon and T.R. Moench, "Vaginal pH and Microbicidal Lactic Acid when Lactobacilli Dominate the Microbiota," Public Library of Science One, vol. 8, no. 11, pp. 800-74, 2013.

[6] F. Nur, Hafsan, and A. Wahdiniar, "Isolasi "Lactic Acid Bacteria with Potential Probiotics in Dangke, Traditional Food from Buffalo Milk in Curio, Enrekang Regency”, Biogenesis, vol. 3, no. 1, pp. 60-5, 2015.

[7] S. Telly and S. Putu, "The Effect Of "Bacteriosin From Lactobacillus acidopillus On Growth Of Salmonella typhi," International Journal Psychosocial Rehabilitation, vol. 24, no. 8, pp. 4382-6, 2020.

[8] A.M. Kusmiati, "Aktivitas "Bacteriocin from Leuconostoc mesenteroides Pbac1 in Various Media“" Makara Kesehatan, vol. 6, no. 1, pp. 1-7, 2012.

[9] N.U. Purwanti and R. Susanti, "Antibacterial and Antifungal Activity Test of Ethanol Extract of Acorus sp," Jurnal Kesehatan Khatulistiwa, vol. 2 , no. 1, pp. 256-268, 2016

[10] R. Sari, L. Deslianri, and P. Apridamayanti, "Antibacterial Activity Screening of Bacteriocin from Ce Hun Tiau Beverage," Pharmaceutical Sciences and Research, vol. 3, no. 2, pp. 88-96, 2016.

[11] E. Rahayu, A. Ekasari, Wardhani, and S. Margino, "Screening of Lactic Acid Bacteria from Meat and Its Processed Products as Bacteriocin Producers," Prosiding Seminar Nasional Pangan, 2000.

[12] Rusli, F. Amalia, and Z. Dwyana, "Potensi "Lactobacillus acidophilus bacteria as Antidiarrheal and Immunomodulator" Jurnal Biologi Makassar, vol. 3,no. 2, pp. 25-30, 2018.

[13] B. Friambodo, Y. Purnomo, and D.A. Ratri, "The effect of the combination of Amoxicillin and Chloramphenicol on the growth of Salmonella typhi bacteria," Journal of Islamic Medical Research, vol. 1, no. 1, pp. 12-20, 2017.

[14] S. Oh, S.H. Kim, and R.W. Worobo, "Characterization and purification of a bacteriocin produced by a potential probiotic culture, Lactobacillus acidophilus 30SC," Journal of Dairy Science, vol. 83, no. 12, pp. $2747-$ $52,2000$.

[15] H. Mahrous, A. Mohamed, M.A. El-Mongy, A.I. El-Batal, and H.A Hamza,. "Study Bacteriocin Production and Optimization Using New Isolates of Lactobacillus spp. Isolated from Some Dairy Products under Different Culture Conditions," Food and Nutrition Sciences, vol. 04, no. 03, pp. 342-56, 2013. 
[16] S.D. Pertami, M. Pancasiyanuar, S.A. Irasari, M.B. Rahardjo, and W. Wasilah, "Lactobacillus acidophilus Probiotic Inhibits the Growth of Candida albicans," Journal of Dentistry Indonesia, vol. 20, no. 3, pp. 64 7, 2013.

[17] C.A. Mirdalisa, Y. Zakaria, and Nurliana, "Effects of Temperature and Shelf Time on Antimicrobial Activity of Fermented Milk with Lactobacillus casei," Agripet, vol. 16, no. 1, pp. 49-55, 2016.

[18] M.H. Bibalan, M. Eshaghi, M. Rohani, M.R. Pourshafie, and M. Talebi, "Determination of bacteriocin genes and antibacterial activity of lactobacillus strains isolated from fecal of healthy individuals," International Journal Molecular and Celluler Medicine, vol. 6, no. 1, pp. $50-5,2017$.

[19] F.W.J. Collins, P.M. O’Connor, O. O'Sullivan, B. Gómez-Sala, M.C. Rea, and C. Hill, "Bacteriocin Gene-Trait matching across the complete
Lactobacillus Pan-genome," Scientific Reports, vol. 7, no. 1, pp. 1-14, 2017.

[20] Y. Masuda H. Ono, H. Kitagawa, H. Ito, F. Mu, and N. Sawa, "Identification and Characterization of Leucocyclicin Q, a Novel Cyclic Bacteriocin Produced by Leuconostoc mesenteroides TK41401," Applied and Environmental Microbiology, vol. 77, no. 22, pp. 8164-70, 2011.

[21] S. Cuozzo, Castellano, F. Sesma, G. Vignolo, and R. Raya, "Differential Roles of The Two-Component Peptides of Lactocin 705 in Antimicrobial Activity," Currrent Microbiology, vol. 46, pp. 180-3, 2013.

[22] I.S. Srionnua, F. Yanagida, L. Lin, K, Hsiao, and Y. Chen, "Weissellicin 110, a Newly Discovered Bacteriocin from Weissella cibaria 110, Isolated from Plaa-Som, a Fermented Fish Product from Thailand," Applied and Environmental Microbiology, vol. 73, no. 7, pp. 1-4, 2007. 